\title{
THE EFFECT OF RISK MANAGEMENT, ACCOUNTABILITY AND MANAGEMENT COMMITMENT ON INTEGRITY SYSTEMS IN THE MALAYSIAN PUBLIC SECTOR
}

\author{
Razana Juhaida Joharia, Jamaliah Said ${ }^{\mathrm{b}}$, Anis Halina Anuar c \\ abc UiTM Shah Alam, Selangor, Malaysia \\ Corresponding email: razana@salam.uitm.edu.my
}

\begin{abstract}
Integrity is considered a vital matter since it may cause governance failures, fraud, inefficiency, corruption and poor financial management, especially in the public sector agency. Currently, the public sector agency has become a global issue as a result of the continuous stream of governance failure, fraud, inefficiency and corruption. Due to that, the agency is under pressure to justify the sources and utilizations of public resources as well as improving the performance in their services since the publics have right to monitor the transparency and efficiency of the public sector's management. This study attempts to investigate the factors that could contribute to the integrity systems in Malaysian public sector. Both printed and online questionnaires were distributed to 210 Heads of Department under selected Malaysian federal ministry. Findings from this study showed a significant positive effect of risk management and accountability practices, as well as the management commitment. This study is expected to contribute to the policy makers by providing them with awareness on the factors that could influence the integrity practices among the department in Malaysian public sector. Research limitation and recommendations for future studies are discussed.
\end{abstract}

Keywords: Pubic Sector, Integrity System, Risk Management, Accountability \& Management Commitment.

\section{Introduction}

The Public sector is an agent that connects the government with the public where the public sector acts on behalf of the public in managing the government trust and providing the services. In other words, public sector conveys the information and resources from the state to the citizens. In order for the public sector to serve these responsibilities, it is vital for the public sector to be transparent, efficient, high integrity and ethical. The government of Malaysia is aware that the public sector is an important agency in public management and administration. Hence, to ensure the problem of misconduct, fraud and corruption from happening, integrity practices are instilled in each department in public sector. The integrity practice is important because it supports good moral values and liberates each department of public sector from unethical conduct which resulted to governance failure.

Based on the Webster's Dictionary, integrity is defined as a 'quality or state of being complete, wholeness, entireness, being of sound moral principle, uprightness, honesty, sincerity and unbroken state.' Even though this definition can be a good descriptive starting point, it does not clearly state if the concept of integrity implies action (Trevinyo-Rodriguez, 2007). The concept and theory of integrity have been discussed thoroughly by many authors and in different fields such as in ethics literature area, organizational behavior, human resources management, psychology and also in leadership (Bauman, 2013; Trevinyo-Rodriguez, 2007). 
According to Chabrak (2015), integrity is considered as honoring one's word because by doing so, individuals create a whole and complete social and working relationship with others and an actionable pathway to being whole and complete with oneself, in which it will reflect the organization's integrity practices. Integrity for organizations is just as important as for individuals since an organization also involves people and the relationship with each other is quite important in ensuring that the organization thrives among its competitors (Said \& Omar, 2014). In an organization's viewpoint, integrity not only refers to being corrupted or fraudulent, but it also lies in the quality or characteristic of individuals (Said, Alam \& Khalid, 2016). In other words, a person who wants to manage integrity of an organization has to have integrity for himself first because a person who is out of integrity most likely will not be in integrity with others (Chabrak, 2015; Kaptein, 2003).

In addition, integrity plays a greater role in mitigating fraud from happening and to pursuit integrity is by working with organizational norms like trust and mutual respect (Chen, Cumming, Hou \& Lee, 2013). The strength of integrity is indicated by a good balance between external demand values and perceived needs, which are rooted from culture that takes external performance responsibilities particularly to the public (Said et al., 2016).Therefore, to ensure a better public sector, understanding the factors influencing integrity system in public sector is very important. In line with that, to determine and explore the factors that contributes to integrity system in the public sector; this study discusses the relationship of risk management, accountability and management commitment in influencing integrity system in the public sector. This study is expected to help the policy makers by providing them awareness on the factors that could influence the integrity practices among the department in Malaysian public sector.

\section{Factors Contributes to Integrity System}

This study considered the following factors which contribute to the integrity system in order to explore their relationship in the Malaysian public sector.

\subsection{Risk Management}

Risk management can be considered as an effective way in assessing, detecting and managing the risk that arise in the organization. Financial crisis and unexpected collapse of many corporations and banks in the United States (US) have resulted in relentless consequences, including reduced economic activity, loss of public confidence and unstable financial system in which all these problems make internal control an essential part of the organization (Ng et al., 2013).

$\mathrm{Ng}$ et al. (2013) stated that risks in the organization may also arise due to the independency of the board's members. This is because when the members are independent, the problem of conflict of interest may be avoided since the independence of the member in the committee will prevent them from having personal interest and this allows them to make fair judgment without fear and favor. According to Rasid et al. (2011), risk is danger, loss, injury or other adverse consequences which can threaten the entire financial system of the organization and it includes the corporate scandals of Enron and WorldCom that collapsed because of fraudulent activity. So, if the directors could seize corporate opportunity without much restriction like risk management and other internal control, the company's interests and business integrity would be at great risk (Ma, 2016). In other words, risk management has a relationship with integrity systems since it can influence and impair integrity as a whole. 


\subsection{Accountability}

Accountability is related to trust and transparency of individuals towards something. The same goes for integrity where it is about honoring one's word (Chabrak, 2015). A study conducted by Said and Jaafar (2014) identified that the employees feel that the top management in their organization is not very transparent. Besides, the organization also needs to uphold and apply the principles of equality and diversity to ensure that they are fair and open to all communities. This situation of transparency and equality have presented the same meaning of integrity attributes of individual based on Said and Omar (2014) in which integrity is referred to as the characteristics that only humans can have.

Even in literature, there is a connection of accountability with the integrity system. This is because the integrity system placed by the department in the public sector has a positive impact in nurturing the accountability in the department which leads to enhancing public sector accountability as general (Aziz et al., 2015). Similar to the study by Jayasinghe and Soobaroyen (2009), they stated that in maintaining accountability, the issues of transparency and trust are very crucial because without these two concepts of integrity, it is difficult for organizations to maintain any form of accountability. This is because accountability is conveyed as an image of trustworthiness and transparency of public sector to the public.

\subsection{Management Commitment}

In the study by Metcalfe and Dick (2001), they found that organizational commitment is significantly influenced on how the employees are managed in an organization. In other words, the commitment is shaped by the way an individual is managed.It is claimed that the commitment from management or organization is really important since it can have an impact on the behavior and commitment from employees as well. Since managerial commitment could affect the behavior of employees, as a leader or manager of the company, what the leader does will be followed by the subordinated, and the same goes for integrity. If the manager is not showing integrity or being ethical in performing the job, the employee would do the same thing like their leaders do. Leaders who provide their team with definite sense of direction and purpose tend to have more satisfied and committed employees.

The study by Leroy et al. (2012) stated that the existence of relationship between management and integrity when the authors found significant relationship between managers commitment and behavioral integrity. These two variables are connected to each other since the employees perceive authentic leadership from the manager's commitment. Hopkin (2007) added that to become a successful manager with high commitment towards employees, it is very crucial to build a trust with the teams they work with and depend on. This is because by developing trust and leading with integrity, it may increase the confidence that employees have in the managers' work.

\section{Methodology}

\subsection{Sampling and Data Collection}

The target population chosen was the federal ministry in Malaysian public sector. Based on three consecutive years of Auditor General Report (i.e. year 2012, 2013 and 2014), there are six ministries identified due to the three consecutive repeated issues being highlighted by the Auditor General. The six ministries involved in this study are (i) the Ministry of Communication and Multimedia, (ii) the Ministry of Education, (iii) the Ministry of Health, (iv) the Ministry of Defense, (v) the Ministry of Agriculture and Agro-Based Industry and (vi) the Ministry of Rural 
and Regional Development. Based on the Auditor General Report 2012, 2013 and 2014, all these six ministries were regularly reprimanded for three consecutive years related to various governmental issues like accountability, ethicality, integrity and mismanagement. The samples of this study are the sub-departments listed under each of the ministry where the database on the number of sub-department was derived from each of the ministry and department official website respectively. Therefore, in total, there are 402 sub-departments under the selected ministry.

The sample is based on the recommendation made by Sekaran and Bougie(2013) where they recommended that a good sample should have not less than 30 samples size and not more than 500 samples in which the acceptance minimum size is according to the number of variables of the study. It is stated that the sample sizes for 400 items are 210 samples (Sekaran \& Bougie, 2013). Therefore, for this study, the selected samples are 210 sub-departments from a total of 402 sub-departments identified from the six ministries. Two hundred and ten (210) samples were selected based on the systematic random sampling technique whereby each element in the population is selected according to a random starting point and a fixed periodic interval. A systematic random sampling is employed by taking every two listed department in each ministry selected in this study. Based on the sample, a total of 210 questionnaires were distributed to the Head of Department (HOD) of sub-department. The questionnaires are administered through two methods which are directly sending by hand to the contact person and through e-mail by using Google Doc application. The method of emailing is used only to the respondents who are unable to be approached, so the email was sent for them to answer.

Out of 210 questionnaires distributed, only 194 questionnaires were collected and responded. The response rate obtained for this study (i.e. 92.4\%) is higher compared to previous study that used the same sample (i.e. Rosli et al., 2015 with $49.5 \%$ response rate). The public sector department involved in this study was contacted earlier to confirm the participation and the contact person is appointed to help in distributing and collecting the questionnaires. Besides that, the respondents involved through emailing were given a gentle reminder on the invitation to participate in this research in order to remind them if in case they may have forgotten. Hence, this study had obtained a high response rate as compared to the previous study.

\subsection{Measurement of Variables}

This study used thirteen items to measure practices of integrity system and the other three factors that contribute to integrity system was measured with several items of question. The items of the variables were adapted from several authors such as from Malaysian Integrity System (2012) namely Corporate Integrity Assessment Questionnaire (CIAQ), Mancuso (2012), Shaoul, Stafford and Stapleton (2012), Gollmar (2008) and Hopkins, O'Neil and Williams (2007).A five-point Likert-type rating scale ranging from 1 (strongly disagree) to 5 (strongly agree) was used in the questionnaire.

\section{Findings and Discussions}

\subsection{Demographic Information}

Demographic information is the descriptive data which is used to explain the characteristics of the sample. In the last section of the questionnaire, the respondents were asked about their demographic information which includes gender, race,age, qualification of academic, type of qualification, job position, department, grade and working experience. 194 out of 210 respondents have completed the survey on the integrity system in the public sector. 59.3\% of the 
respondents or 115 out of 194 respondents were female while another 79 respondents were male. From the analysis, majority of the respondents were Malays with $90.7 \%$ or 176 respondents, $5.7 \%$ or 11 respondents were Indians while another $3.6 \%$ or 7 respondents were Chinese. For age group, the major respondents who filled in this survey fell in the category of 41 to 50 years old which comprised of $38.1 \%$ from the total respondents and the lowest percentage comes from age 20 to 30 years with only $12.4 \%$. For academic qualification, majority of the respondents have acquired at least a bachelor degree which comprises of $51.5 \%$ while the remaining comes from Master and $\mathrm{PhD}$ level with $46.4 \%$ and $2.1 \%$ respectively. Meanwhile, for types of qualification, it shows that most of the respondents have an accounting background with 50.5\%. In terms of job position, majority of the respondents were in management and professional position with $90.7 \%$ or 176 respondents whereby they were responsible in managing and making decision for their departments.

For the department in the organization, $40.2 \%$ or 78 respondents come from the administrative department, $23.7 \%$ or 46 respondents from finance, $23.2 \%$ or 45 respondents from accounting department, $5.2 \%$ or 10 respondents from audit department, 2 respondents each for education and information system department and the rest $5.7 \%$ or 11 respondents from other departments. From the analysis, other departments consisted of the officers from legal department, tax department, health department and some of them were in the procurement department. The respondents were also asked about their service grade in the public sector. About $52.1 \%$ of the respondents were in grade 41 , followed by grade 48 with $36.1 \%, 10.8 \%$ from grade 44 and another $1.0 \%$ from grade 52 . The last two questions were about the respondent's working experience in the current organization and also their working experience in the public sector. About $77.3 \%$ of the respondents have been working for more than 5 years in their current organization while $11.9 \%$ of the respondents have been working between 4 to 5 years. Only $5.7 \%$ of the respondents have indicated that they served their current organization for less than 1 year. As for working in the public sector, $67.0 \%$ of the respondents stated that they have served the public sector for more than 5 years. Meanwhile, the remaining respondents have served the government below 4 years which indicates that the respondents have little working experience in the public sector.

\subsection{Descriptive Analysis}

Referring to the table 1, the highest mean score for integrity system is question IS 5 with a mean of 4.54 (standard deviation $=.603$ ) while the lowest mean score is question IS 13 with a mean score of 3.99 (standard deviation $=.444$ ). This result implies that from the respondent's point of view, their department believed that they can easily identify ethical and integrity leader among the top managers. However, they seem to believe that their department has the least support in promoting integrity conducts as part of the activities in their department. 
Table 1: Descriptive Statistics on Integrity System

\begin{tabular}{ccccccc}
\hline Questions & $\mathbf{N}$ & Minimum & Maximum & Mean & SD & Variance \\
\hline IS 1 & 194 & 2.00 & 5.00 & 4.5361 & .62854 & .395 \\
IS 2 & 194 & 2.00 & 5.00 & 4.0773 & .46561 & .217 \\
IS 3 & 194 & 3.00 & 5.00 & 4.2887 & .52815 & .279 \\
IS 4 & 194 & 3.00 & 5.00 & 4.2577 & .54399 & .296 \\
IS 5 & 194 & 3.00 & 5.00 & 4.5412 & .60297 & .364 \\
IS 6 & 194 & 2.00 & 5.00 & 4.2629 & .65812 & .433 \\
IS 7 & 194 & 1.00 & 5.00 & 4.1289 & .80084 & .641 \\
IS 8 & 194 & 2.00 & 5.00 & 4.0670 & .80840 & .654 \\
IS 9 & 194 & 1.00 & 5.00 & 4.2062 & .75410 & .569 \\
IS 10 & 194 & 2.00 & 5.00 & 4.0000 & .43189 & .187 \\
IS 11 & 194 & 2.00 & 5.00 & 4.0258 & .38677 & .150 \\
IS 12 & 194 & 2.00 & 5.00 & 4.1959 & .68499 & .469 \\
IS 13 & 194 & 2.00 & 5.00 & 3.9897 & .44360 & .197 \\
Valid N & 194 & & & & & \\
(listwise) & & & & & & \\
\hline
\end{tabular}

\subsection{Normality Test}

In this study, skewness and kurtosis tests were used as indicators to test the assumption of normal distribution. The rule of thumb for skewness and kurtosis to be normally distributed is that the values must be between -2 and +2 . If the values of skewness and kurtosis fall in that range, it means that the distribution of the data is normal. The results in this study showed that the value of skewness and kurtosis for all variables are not normally distributed (Table 2). However, according to Field (2013), even though the data are not normally distributed but the data are more than 30 samples, it is considered to be normal. Therefore, as mentioned by the author, the data of this study is considered as normal since the sample of this study more than 30 samples which is 210 samples; even though the values of skewness and kurtosis are not within the range of $-/+2$.

Table 2: Normality test of sample distribution

\begin{tabular}{lccccc}
\hline & $\mathbf{N}$ & \multicolumn{2}{c}{ Skewness } & \multicolumn{2}{c}{ Kurtosis } \\
\cline { 2 - 6 } & Statistic & Statistic & $\begin{array}{c}\text { Std. } \\
\text { Error }\end{array}$ & Statistic & $\begin{array}{c}\text { Std. } \\
\text { Error }\end{array}$ \\
\hline Integrity System & 194 & -3.006 & .175 & 13.539 & .347 \\
Risk management & 194 & -1.836 & .175 & 17.503 & .347 \\
Accountability & 194 & -2.206 & .175 & 6.281 & .347 \\
$\begin{array}{l}\text { Management } \\
\text { Commitment }\end{array}$ & 194 & -3.548 & .175 & 16.779 & .347 \\
\hline
\end{tabular}




\subsection{Validity Test}

In order to test the validity of the instrument, this study uses factor analysis method. This test is used to measure the consistency of the items in the questionnaire in order to know whether the questions being asked are suitable or not to be used in the study. The value of Kaiser-MeyerOlkin Measure of Sampling Adequacy (KMO) should be .6 or above in order to ensure that the data set used is suitable for factor analysis. Besides that, the factor loading .30 was considered as the minimal level of the factor loading for each item while the factor loading greater than .50 was considered as important and significant. Therefore, any factor loading below than the minimal level of .30 was eliminated in order to get the most significant value. Based on the results of factor analysis, all variables show the value of Kaiser-Meyer Olkin is greater than .6 except the variable of management commitment who has value lower than .6. However, the value of KMO for management commitment variable is greater than .6 when the item with the lowest factor loading was eliminated. Hence, all variables were adequate to be used in this study.

Table 3: Factor Analysis

\begin{tabular}{lccccc}
\hline & IS & RM & AC & MC & $\begin{array}{c}\text { MC after } \\
\text { elimination } \\
\text { of item }\end{array}$ \\
\hline Eigen \% variance & $77.811 \%$ & $82.305 \%$ & $82.606 \%$ & $90.00 \%$ & $91.22 \%$ \\
\% of variance & $77.811 \%$ & $82.305 \%$ & $82.606 \%$ & $90.00 \%$ & $91.22 \%$ \\
$\begin{array}{l}\text { KMO Measure of } \\
\text { Sampling Adequacy }\end{array}$ & .751 & .662 & .600 & .555 & .726 \\
$\begin{array}{l}\text { Barlett's Test of } \\
\begin{array}{l}\text { Sphericity } \\
\text {-Approx. Chi-Square }\end{array}\end{array}$ & 2360.355 & 2866.319 & 2616.499 & 2543.424 & 2056.112 \\
Sig & .000 & .000 & .000 & .000 & .000 \\
\hline
\end{tabular}

\subsection{Reliability Test}

In order to test the reliability of the instrument used in this study, Cronbach's alpha is the method used for the purpose of this study. From Table 4, it shows the result of reliability test for all variables. All the variables such as integrity system, risk management, accountability and management commitment have the reliability that higher than .8 which considered as good and high. Therefore, it can be observed that most of the variables were positively contributing to the overall reliability.

Table 4: Reliability test

\begin{tabular}{ccc}
\hline Reliability Coefficients & $\begin{array}{c}\text { Cronbach } \\
\text { Alpha }\end{array}$ & $\begin{array}{c}\text { Cronbach Alpha Based } \\
\text { on Standardized Items }\end{array}$ \\
\hline Integrity System & .890 & .897 \\
Risk Management & .896 & .898 \\
Accountability & .827 & .834 \\
Management Commitment & .877 & .880 \\
\hline
\end{tabular}




\subsection{Correlation Analysis}

In this study, to measure the association of two variables, the Pearson Correlation or known as Pearson Product-Moment Correlation Coefficient is used. A correlation between variables is high when the value of $\mathrm{r}=+/-.7$ to 1.00. Based on Table 5 , it shows that all variables shown a high positive correlation between each other since the value of $\mathrm{r}$ is higher than .7 for all variables.

Table 5: Pearson' Correlation

\begin{tabular}{|c|c|c|c|c|c|}
\hline & & IS & $\mathbf{R M}$ & $\mathbf{A C}$ & MC \\
\hline IS & $\begin{array}{l}\text { Pearson Correlation } \\
\text { Sig. (2-tailed) }\end{array}$ & 1 & & & \\
\hline $\mathbf{R M}$ & $\begin{array}{l}\text { Pearson Correlation } \\
\text { Sig. (2-tailed) }\end{array}$ & $\begin{array}{l}.854^{* *} \\
.000\end{array}$ & 1 & & \\
\hline $\mathbf{A C}$ & $\begin{array}{l}\text { Pearson Correlation } \\
\text { Sig. (2-tailed) }\end{array}$ & $\begin{array}{l}.831^{* * *} \\
.000\end{array}$ & $\begin{array}{l}.758^{* * *} \\
.000\end{array}$ & 1 & \\
\hline MC & $\begin{array}{l}\text { Pearson Correlation } \\
\text { Sig. (2-tailed) }\end{array}$ & $\begin{array}{l}.891^{* * *} \\
.000\end{array}$ & $\begin{array}{l}.839^{* * *} \\
.000\end{array}$ & $\begin{array}{l}.907^{* * *} \\
.000\end{array}$ & 1 \\
\hline
\end{tabular}

\subsection{Multiple Regression Analysis}

Table 6 shows the significant value at $5 \%(\mathrm{~F}=320.365, \mathrm{p}=.000)$ which mean that there is sufficient evidence showing that at least one independent variable in this study affects the integrity system variable.

Table 6: ANOVA

\begin{tabular}{lccccc}
\hline Model & Sum of Square & df & Mean Square & F & Sig. \\
& & & & & \\
\hline Regression & 23.583 & 3 & 7.861 & 320.365 & $.000^{\mathrm{b}}$ \\
Residual & 4.662 & 190 & .025 & & \\
Total & 28.245 & 193 & & & \\
\hline
\end{tabular}

a. Dependent Variable: Integrity System

b. Predictors: (Constant), Risk Management, Accountability, Management Commitment

Based on Regression analysis on Table 7, it reveals the overall results for this study. Based on the table, risk management shows a significant positive relationship with integrity system when the coefficient for risk management is $.361, \mathrm{t}=6.664, \mathrm{p}=.000$ where $\mathrm{p}<.05$. The beta coefficient for risk management (.361) indicates that every 1 rise in risk management could enhance the integrity system by .361. Therefore, the first hypothesis (H1) is supported. 
Meanwhile, accountability also shows a significant positive relationship with integrity system when the value of coefficient is $.135, \mathrm{t}=1.931, \mathrm{p}=.055$ where $\mathrm{p}<.10$. So, as a result, the second hypothesis (H2) is supported. Finally, the variable management commitment shows a significant positive relationship with integrity system when the value of coefficient is $.466, t=$ $5.564, p=.000$ where $p<.05$. The beta coefficient for management commitment (.466) indicates that every 1 rise in the management commitment could enhance the integrity system by .466 . Therefore, the third hypothesis $\left(\mathrm{H}_{3}\right)$ is also supported.

Table 7: Regression Analysis

\begin{tabular}{|c|c|c|c|c|}
\hline Model & $\begin{array}{c}\text { Standardize } \\
\text { Coefficient (Beta) }\end{array}$ & $\begin{array}{l}\text { Std. } \\
\text { Error }\end{array}$ & $\begin{array}{c}\mathrm{t}- \\
\text { statistic }\end{array}$ & Sig. \\
\hline (Constant) & & .148 & 2.117 & .036 \\
\hline Risk Management & .361 & .042 & 6.664 & $.000^{*}$ \\
\hline Accountability & .135 & .079 & 1.931 & $.055^{* *}$ \\
\hline Management Commitment & .466 & .081 & 5.564 & $.000^{*}$ \\
\hline $\begin{array}{ll}\mathrm{R} \\
\mathrm{R}^{2}=.835 \\
\text { Adjusted } \\
\text { F-statisti } \\
{ }^{*} \text { Signific }\end{array}$ & $\begin{array}{l}\quad=.914 \\
2=.832 \\
(p-\text { value })=320.365 \\
\text { ce at } p<0.05,{ }^{* *} \text { Sign }\end{array}$ & nce at & & \\
\hline
\end{tabular}

\section{Conclusion}

The aims of Malaysia are to achieve Vision 2020 by becoming a high nation economy and a developed nation. However, many steps should be taken to improve the integrity of the public sector. This study tries to measure the relationship between the factor of risk management, accountability and management commitment with the integrity practices in the Malaysian public sector. The regression result showed that all the factors of risk management, accountability and management commitment have statistically significant positive relationship with the practices of integrity in the public sector of Malaysia. Therefore, it is proven that the establishments of risk management policy, high level of accountability and strong management commitment by department have accomplished the objectives of the stakeholder in this country in improving integrity of public sector. It is very important for the organization to implement or establish risk management policy, insert a high level of accountability and have a high commitment from the management since the public sector is currently being accused for being inflexible in carrying out their daily activities. Therefore, it is suggested that every department in the ministry produces a report regarding the ethics and integrity activities organized by them in order to develop good governance.The findings of this study are expected to contribute to the policy makers by providing them with awareness on the factors that could influence the integrity practices among the department in Malaysian public sector.

\section{Acknowledgements}

The research was supported by the Ministry of Education Malaysia through Accounting Research S Institute (ARI), Universiti Teknologi MARA. We also acknowledged the assistance rendered to us by the Research Management Institute of UiTM. 


\section{References}

i. Aziz, M., Rahman, H., Alam, M. \& Said, J., 2015. Enhancement of teh Accountability of Public Sectors through Integrity System, Internal Control System and Leadership Practices: A Review Study. Procedia Economics and Finance, 5671(15), pp. 163-169.

ii. Bauman, D., 2013. Leadership and the Three Faces of Integrity. the Leadership Quartely, Volume 24, pp. 414-426.

iii. Chabrak, N., 2015. Promoting Corporate Social Responsibility and Sustainability: A Model of Integrity. Society and Business Review, 10(3), pp. 280-305.

iv. Chen, J., Cumming, D., Hou, W. \& Lee, E., 2013. Executive Integrity, Audit Opinion and Fraud in Chinese Listed Firms. Emerging Market Reviews, Volume 15, pp. 72-91.

v. Field, A., 2013. Discovering Statistics Using IBM SPSS Statistics. 4th ed. s.l.:Sage Publications .

vi. Hopkins, M., O'Neil, D. \& Williams, H., 2007. Emotional Intelligence and Board Governance Leadership Lessons from the Public Sector. Journal of Managerial Psychology, 22(7), pp. 683-700.

vii. Jayasinghe, K. \& Soobaroyen, T., 2009. Religious Spirit and People's Perceptions of Accountability in Hindu and Buddhist Religious Organizations. Accounting, Auditing, and Accountability Journal , 22(7), pp. 997-1028.

viii. Kaptein, M., 2003. The Diamond of Managerial Integrity. European Management Journal , 21(1), pp. 99-108.

ix. Leroy, H., Palanski, M. \& Simons, T., 2012. Authentic Leadership and Behavioral Integrity as Drivers of Follower Commitment and Performance. Journal of Business Ethics, Volume 3, pp. 255-264.

x. Ma, F., 2016. Business integrity v. Business Efficiency: The Corporate Opportunity Doctrine in China. Journal of Financial Crime, 23(1), pp. 201-215.

xi. Mancuso, M., 2012. Non-profit Risk Management. the Philanthropist, 24(3).

xii. Metcalfe, B. \& Dick, G., 2001. Exploring Organisation Commitment in the Police - Implications for Human Resource Strategy. Policing. An International Journal of Police Strategies \& Management, 24(3), pp. 399-419.

xiii. Ng, T., Chong, L. \& Ismail, H., 2013. Is the Risk Management Committee Only A Procedural Compliance?. The Journal of Risk Finance, 14(1), pp. 71-86.

xiv. Rasid, S., Rahman, A. \& Ismail, W., 2011. Management Accounting and Risk Management in Malaysian Financial Institutions.. Managerial Auditing Journal , 26(7), pp. 566-585.

xv. $\quad$ Rosli, M., Aziz, M., Mohd, F. \& Said, J., 2015. Integrity Systems in Malaysian Public Sector: An Empirical Finding. Procedia Economics and Finance, Volume 28, pp. 260-265.

xvi. Said, J., Alam, M. \& Khalid, M., 2016. Relationship Between Good Governance And Integrity System: Empirical Study on the Public Sector of Malaysia. Humanomics, 32(2).

xvii. Said, J. \& N.H.Jaafar, 2014. Accountability in Government Linked Companies: An Empirical Finding. Procedia - Social and Behavioral Sciences.

xviii. Said, J. \& Omar, N., 2014. Corporate Integrity System: Comparative Analysis of Two Giant Government Linked Companies. Procedia - Social and Behavioral Sciences, pp. 12-17.

xix. $\quad$ Sekaran, U. \& Bougie, R., 2013. Research Methods for Business. 6th ed. s.l.:s.n. 


\section{Asia Pacific Journal of Advanced Business and Social Studies \\ ISBN (eBook): 9780994365675 | ISSN : 2205-6033 \\ Year: 2017 , Volume: 3, Issue: 2}

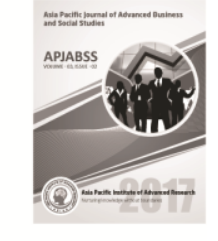

xx. Shaoul, J., Stafford, A. \& P.Stapleton, 2012. Accountability and Corporate Governance of Public Private Partnerships. Critical Perspectives on Accounting, 23(3), pp. 213-229.. [Online] Available at: http://dx.doi.org/10.1016/j.cpa.2011.12.006

xxi. System, M. I., 2012. A Consultative Document on Corporate Integrity System Assessment Questionnaire: Corporate Integrity System Malaysia 2010-2012, s.l.: Malaysian Integrity System.

xxii. Trevinyo-Rodriguez, R., 2007. Integrity: A System Theory Classification.. Journal of Management History, 13(1), pp. 74-93. 